\title{
GMR
}

\section{A snapshot on prokaryotic diversity of the Solimões River basin (Amazon, Brazil)}

\author{
D. Toyama ${ }^{1}$, C.D. Santos-Júnior ${ }^{1}$, L.T. Kishi ${ }^{1}$, T.C.S. Oliveira ${ }^{2}$, J.W. Garcia ${ }^{3}$, \\ H. Sarmento ${ }^{4}$, F.P. Miranda ${ }^{5}$ and F. Henrique-Silva ${ }^{1}$ \\ ${ }^{1}$ Laboratório de Biologia Molecular, Departamento de Genética e Evolução, \\ Universidade Federal de São Carlos, São Carlos, SP, Brasil \\ ${ }^{2}$ Departamento de Química, Universidade Federal do Amazonas, \\ Manaus, AM, Brasil \\ ${ }^{3}$ Noosfera Projetos Especiais Ltda., São Paulo, SP, Brasil \\ ${ }^{4}$ Laboratório de Biodiversidade e Processos Microbianos, \\ Departamento de Hidrobiologia, Universidade Federal de São Carlos, \\ São Carlos, SP, Brasil \\ ${ }^{5}$ Petróleo Brasileiro S.A., \\ Centro de Pesquisas e Desenvolvimento Leopoldo Américo Miguez de Mello, \\ Rio de Janeiro, RJ, Brasil \\ Corresponding author: F. Henrique-Silva \\ E-mail:dfhs@ufscar.br
}

Genet. Mol. Res. 16 (2): gmr16029567

Received December 8, 2016

Accepted April 7, 2017

Published May 18, 2017

DOI http://dx.doi.org/10.4238/gmr16029567

Copyright (C) 2017 The Authors. This is an open-access article distributed under the terms of the Creative Commons Attribution ShareAlike (CC BY-SA) 4.0 License.

ABSTRACT. The Amazon region has the largest hydrographic basin
on the planet and is well known for its huge biodiversity of plants
and animals. However, there is a lack of studies on aquatic microbial
biodiversity in the Solimões River, one of its main water courses. To
investigate the microbial biodiversity of this region, we performed 16S
rRNA gene clone libraries from Solimões River and adjacent rivers and
lakes. Our question was which microorganisms inhabit the different
types of aquatic environments in this part of the basin, and how diversity
varies among these environments (rivers and lakes). The microbial
diversity generating 13 clone libraries of the bacterial 16S rRNA gene

Genetics and Molecular Research 16 (2): gmr16029567 
and 5 libraries of the archaeal 16S rRNA gene was assessed. Diversity measured by several alpha diversity indices (ACE, Chao, Shannon and Simpson) revealed significant differences in diversity indices between lake and river samples. The site with higher microbial diversity was in the Solimões River (4S), downstream the confluence with Purus River. The most common bacterial taxon was the cosmopolitan Polynucleobacter genus, widely observed in all samples. The phylum Thaumarchaeota was the prevailing archaeal taxon. Our results provide the first insight into the microbial diversity of the world's largest river basin.

Key words: Amazon; Freshwater; Clone libraries; 16S rRNA gene; Bacteria; Archaea

\section{INTRODUCTION}

The Solimões/Amazon River forms a huge floodplain which extends for about 1700 $\mathrm{km}$ from its Andean headwaters to reach the Atlantic Ocean. This fluvial system transports about $1240 \mathrm{Mt} /$ year of sediments of Andean erosion and reworks $3200 \mathrm{Mt} /$ year of floodplain sediments (Mertes et al., 1996). Its yearly discharge of 6.3 trillion $\mathrm{m}^{3}$ is about $16 \%$ of all freshwater released into the oceans of the world (Oltman, 1968).

The Amazon region is the world's largest rainforest that is inhabited of an extensive biodiversity, including fauna, flora, with numerous endemic species. However, much of the microbiota present in this region has been largely unexplored and little information about the microbial communities of the Solimões-Amazon River and other waterbodies in this remote region is available for the scientific community (Ghai et al., 2011; Satinsky et al., 2015; Toyama et al., 2016; Santos-Júnior et al., 2017).

Amazonian aquatic ecosystems are generally supersaturated in $\mathrm{CO}_{2}$, and most of this carbon comes from in situ (mostly microbial) respiration of organic carbon (Mayorga et al., 2005). Despite their important role on carbon biogeochemistry, little is known about the aquatic microbial diversity in the Amazonian basin. The analysis of $16 \mathrm{~S}$ ribosomal RNA genes has been widely used for taxonomic studies and bacterial species identification. Analysis based on the 16S rRNA gene has enabled the identification of a variety of a yet not-cultivated bacteria. This approach can also reveal features of biotechnological interest and enable the identification of archaea in non-extreme environments (Chaban et al., 2006).

Studies that used cultivation-independent methods to explore freshwater environments revealed a ubiquitous distribution of Betaproteobacteria (Zwart et al., 2002; Jezberová et al., 2010) and bacteria from the phylum Actinobacteria (Lindström et al., 2005; Newton et al., 2007; Jezbera et al., 2009). The phyla Cyanobacteria, Bacteroidetes, Verrucomicrobia, and Planctomycetes also represent frequently a significant fraction of freshwater communities (Glöckner et al., 1999; Nishimura and Nagata, 2007).

Microbial communities in freshwater environments differ from those of marine and soil. However, these communities can also vary among types of freshwater environments. Several factors determine the composition of microbial communities of lakes such as $\mathrm{pH}$, temperature, hydrological retention time, and trophic state (Lindström et al., 2005; Newton et al., 2007). Furthermore, despite some differences pertaining to characteristics of each environment, comparisons between microbial communities in rivers and lakes have shown

Genetics and Molecular Research 16 (2): gmr16029567 
similarities in the taxa retrieved, especially in the most abundant organisms described as typical freshwater bacteria (Lemke et al., 2009; Read et al., 2015). Rivers also have a large number of possible inputs, both natural and anthropogenic, which might bring additional taxa to microbial communities. These communities may also respond differently to the lotic environment, mainly to aspects related to water residence time, since some bacteria have slower growth rates and may become part of the community or decrease over the course of the river (Read et al., 2015).

The study of aquatic microbial diversity in the Amazon region is in its infancy. A metagenomic study carried out in one single sample of river water of the Solimões River revealed a large microbial diversity and a vast array of potential metabolisms (Ghai et al., 2011). More recently, Satinsky et al. (2015) studied the microbial communities in the lower Amazon River closer to the river mouth. However, understanding the main drivers of spatial and temporal dynamics in such a large and heterogeneous ecosystem remains a major challenge.

Considering our limited knowledge on the microbial diversity of this hydrographic basin, the aim of this study was to provide insights into the composition of the microbial community in the upper Solimões River, and some of its tributaries (Purus and Urucu Rivers) and adjacent lakes, in order to elucidate which microorganisms inhabit the different types of aquatic environments of the river basin, and how diversity varies among these environments (rivers and lakes).

\section{MATERIAL AND METHODS}

\section{Sampling and limnological parameters}

Sampling took place in September 2008 in the upper Solimões, Urucu, and Purus Rivers and some adjacent lakes, between the cities of Manaus and Coari, in the Amazon State of Brazil (Figure 1 and Table 1). Water samples were collected at $50 \%$ of water column depth at each sample point, which ranged from 1 to $17 \mathrm{~m}$, using a 10-L Van Dorn bottle. For DNA extraction, water samples were filtered with a peristaltic pump and a 142-mm diameter standing stainless steel filter holder (Millipore) with an AP 20 glass microfiber membrane and a 5-mm isopore polycarbonate membrane (142 $\mathrm{mm}$ in diameter, Millipore) and a 0.22-mm PVDF filter (Sterivex GV, Millipore), in which the bacteria and archaea in the water were retained.

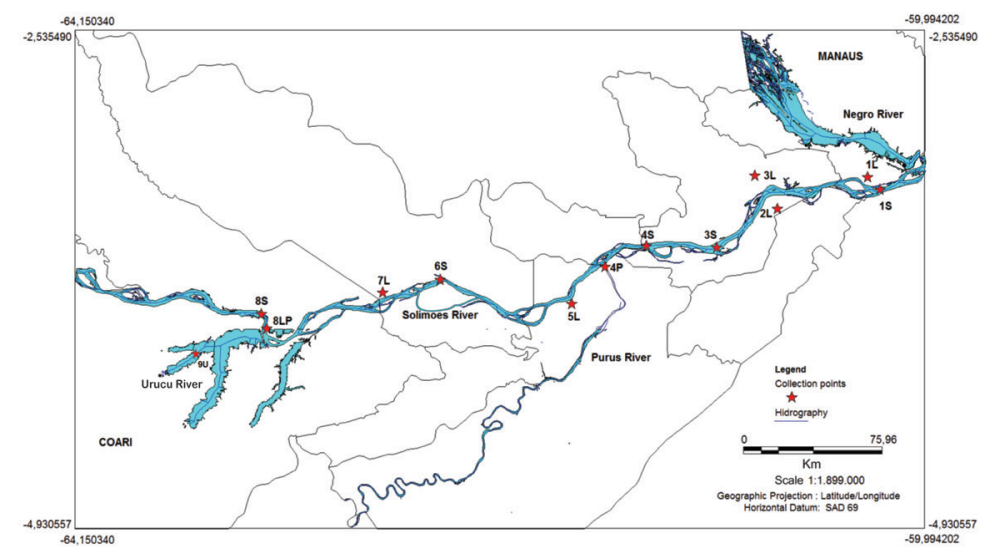

Figure 1. Wide picture of water sampling points. Letters indicate the location of the sampling sites as follows: S, Solimões River sampling points; L, lake sampling points; U, Urucu River; P, Purus River; LP, Lake Poraquê. 
Table 1. Detailed description of the sampling sites.

\begin{tabular}{|c|c|c|c|c|}
\hline Sampling sites & Coordinates (GPS) & Abbreviation on the map & Characteristics of the sampling site & Additional information \\
\hline Lake Poraquê & $\begin{array}{l}03^{\circ} 57^{\prime} 36.36^{\prime \prime} \mathrm{S} ; \\
63^{\circ} 09^{\prime} 48.17^{\prime \prime} \mathrm{W}\end{array}$ & $8 \mathrm{LP}$ & $\begin{array}{l}\text { Depth: } 1.8 \mathrm{~m} \\
\text { Sampling depth: } 1 \mathrm{~m} \\
\text { Black water }\end{array}$ & $\begin{array}{l}\text { Sampling date: } 09 / 17 / 2008 \\
\text { Sampling time: } 10: 10 \mathrm{am} \\
\text { Water temperature } 26.6^{\circ} \mathrm{C} \\
\text { Oxygen: } 2.20 \mathrm{mg} / \mathrm{L} \\
\text { Conductivity: } 17.3 \mu \mathrm{S} / \mathrm{cm} \\
\text { pH: } 5.0 \\
\text { Water transparency: } 50 \mathrm{~cm} \\
\text { Suspended material }(\mathrm{mg} / \mathrm{L}): 17 \\
\text { BOD }(\mathrm{mg} / \mathrm{L}): 2.58\end{array}$ \\
\hline Lake Sodré or Lake Jacaré & $\begin{array}{l}03^{\circ} 49^{\prime} 56.80^{\prime \prime} \mathrm{S} ; \\
62^{\circ} 34^{\prime} 46.45^{\prime \prime} \mathrm{W}\end{array}$ & $7 \mathrm{~L}$ & $\begin{array}{l}\text { Depth: } 3 \mathrm{~m} \\
\text { Sampling depth: } 2 \mathrm{~m}\end{array}$ & $\begin{array}{l}\text { Sampling date: } 09 / 16 / 2008 \\
\text { Sampling time: } 9: 28 \text { am } \\
\text { Limnological analyses were not } \\
\text { performed for this point. }\end{array}$ \\
\hline Lake Ananá & $\begin{array}{l}03^{\circ} 53^{\prime} 11.83^{\prime \prime S} \\
61^{\circ} 40^{\prime} 36.75^{\prime \prime} \mathrm{W}\end{array}$ & $5 \mathrm{~L}$ & \begin{tabular}{|l|} 
Depth: $2 \mathrm{~m}$ \\
Sampling depth: $1 \mathrm{~m}$
\end{tabular} & $\begin{array}{l}\text { Sampling date: } 09 / 14 / 2008 \\
\text { Sampling time: } 9: 03 \mathrm{am} \\
\text { Water temperature: } 29.3^{\circ} \mathrm{C} \\
\text { Oxygen: } 4.14 \mathrm{mg} / \mathrm{L} \\
\text { Conductivity: } 88 \mu \mathrm{S} / \mathrm{cm} \\
\text { pH: } 6.78 \\
\text { Water transparency: } 20 \mathrm{~cm} \\
\text { Turbidity (NTU): } 25.74 \\
\text { Suspended material }(\mathrm{mg} / \mathrm{L}): 47 \\
\text { BOD }(\mathrm{mg} / \mathrm{L}): 3.79\end{array}$ \\
\hline Manacapuru Great Lake & $\begin{array}{l}03^{\circ} 15^{\prime} 50.96^{\prime \prime S} ; \\
60^{\circ} 41^{\prime} 19.76^{\prime \prime W}\end{array}$ & $3 \mathrm{~L}$ & \begin{tabular}{|l|} 
Depth: $11 \mathrm{~m}$ \\
Sampling depth: $5.5 \mathrm{~m}$ \\
Receives water from the Manacapuru \\
River (black water)
\end{tabular} & $\begin{array}{l}\text { Sampling date: } 09 / 11 / 2008 \\
\text { Sampling time: }: 3: 05 \mathrm{pm} \\
\text { Limnological analyses were not } \\
\text { performed for this point. }\end{array}$ \\
\hline Lake Preto & $\begin{array}{l}03^{\circ} 21^{\prime} 12.46^{\prime \prime S} ; \\
60^{\circ} 37^{\prime} 31.30^{\prime \prime} \mathrm{W}\end{array}$ & $2 \mathrm{~L}$ & $\begin{array}{l}\text { Depth } 2 \mathrm{~m} \\
\text { Sampling depth: } 1.5 \mathrm{~m} \\
\text { Does not receive influence of the } \\
\text { Solimōes River } \\
\text { Black water }\end{array}$ & $\begin{array}{l}\text { Sampling date: } 09 / 11 / 2008 \\
\text { Sampling time: } 8: 30 \mathrm{am} \\
\text { Water temperature: } 29.4^{\circ} \mathrm{C} \\
\text { Oyygen: } 3.41 \mathrm{mg} / \mathrm{L} \\
\text { Conductivity: } 63.7 \mu \mathrm{S} / \mathrm{cm} \\
\text { pH: } 6.43 \\
\text { Water transparency: } 80 \mathrm{~cm} \\
\text { Suspended material }(\mathrm{mg} / \mathrm{L}): 58\end{array}$ \\
\hline Lake Baixio & $\begin{array}{l}03^{\circ} 14^{\prime} 55.77^{\prime \prime S} ; \\
60^{\circ} 05^{\prime} 01.43^{\prime \prime} \mathrm{W}\end{array}$ & $1 \mathrm{~L}$ & $\begin{array}{l}\text { Depth: } 2.5 \mathrm{~m} \\
\text { Sampling depth: } 2 \mathrm{~m} \\
\text { Receives influence of the Solimões River }\end{array}$ & $\begin{array}{l}\text { Sampling date: } 09 / 10 / 2008 \\
\text { Sampling time: } 9: 58 \mathrm{am} \\
\text { Water temperature: } 30.7^{\circ} \mathrm{C} \\
\text { Oxygen: } 2.74 \mathrm{mg} / \mathrm{L} \\
\text { Conductivity: } 109.8 \mu \mathrm{S} / \mathrm{cm} \\
\text { pH: } 6.81 \\
\text { Water transparency: } 70 \mathrm{~cm}\end{array}$ \\
\hline The Urucu River Mouth & $\begin{array}{l}04^{\circ} 08^{\prime} 08.03^{\prime \prime S} ; \\
63^{\circ} 29^{\prime} 54.69^{\prime \prime} \mathrm{W}\end{array}$ & $9 \mathrm{U}$ & $\begin{array}{l}\text { Depth: } 2.8 \mathrm{~m} \\
\text { Sampling depth: } 1.5 \mathrm{~m} \\
\text { Black water }\end{array}$ & $\begin{array}{l}\text { Sampling date: } 09 / 18 / 2008 \\
\text { Sampling time: } 9: 54 \mathrm{am} \\
\text { Water temperature: } 28.6^{\circ} \mathrm{C} \\
\text { Oxygen: } 5.75 \mathrm{mg} / \mathrm{L} \\
\text { Conductivity: } 25.8 \mu \mathrm{S} / \mathrm{cm} \\
\text { pH: } 6.46 \\
\text { Water transparency: } 60 \mathrm{~cm} \\
\text { Turbidity (NTU): } 10.92\end{array}$ \\
\hline & & & & $\begin{array}{l}\text { Suspended material }(\mathrm{mg} / \mathrm{L}): 42.50 \\
\text { BOD }(\mathrm{mg} / \mathrm{L}): 3.41\end{array}$ \\
\hline Solimões River upstream of the Solimões Terminal (TSOL) & $\begin{array}{l}03^{\circ} 56^{\prime} 11.08^{\prime \prime S} ; \\
63^{\circ} 10^{\prime} 14.45^{\prime \prime} \mathrm{W}\end{array}$ & $8 \mathrm{~S}$ & \begin{tabular}{|l|} 
Depth: $15 \mathrm{~m}$ \\
Sampling depth: $8 \mathrm{~m}$
\end{tabular} & $\begin{array}{l}\text { Sampling date: } 09 / 17 / 2008 \\
\text { Sampling time: } 1: 54 \mathrm{pm} \\
\text { Water temperature: } 29.8^{\circ} \mathrm{C} \\
\text { Oxygen: } 5.05 \mathrm{mg} / \mathrm{L} \\
\text { Conductivity: } 109.7 \mu \mathrm{S} / \mathrm{cm} \\
\text { pH: } 7.09 \\
\text { Water transparency: } 20 \mathrm{~cm} \\
\text { Turbidity (NTU): } 18.20 \\
\text { Suspended material }(\mathrm{mg} / \mathrm{L}): 45.67 \\
\text { BOD (mg/L): } 2.90\end{array}$ \\
\hline Solimões River & $\begin{array}{l}03^{\circ} 49^{\prime} 52.26^{\prime \prime S} ; \\
62^{\circ} 26^{\prime} 58.46 " \mathrm{~W}\end{array}$ & $6 \mathrm{~S}$ & $\begin{array}{l}\text { Depth: } 22 \mathrm{~m} \\
\text { Sampling depth: } 17 \mathrm{~m}\end{array}$ & $\begin{array}{l}\text { Sampling date: } 09 / 15 / 2008 \\
\text { Sampling time: } 11: 42 \text { am } \\
\text { Limnological analyses were not } \\
\text { performed for this point. }\end{array}$ \\
\hline Purus River Mouth & $\begin{array}{l}03^{\circ} 41^{\prime} 07.45^{\prime \prime S} ; \\
61^{\circ} 28^{\prime} 13.91^{\prime \prime W}\end{array}$ & $4 \mathrm{P}$ & $\begin{array}{l}\text { Depth: } 24 \mathrm{~m} \\
\text { Sampling depth: } 15 \mathrm{~m} \\
\text { White water }\end{array}$ & $\begin{array}{l}\text { Sampling date: } 09 / 13 / 2008 \\
\text { Sampling time: } 8: 00 \text { am } \\
\text { Limnological analyses were not } \\
\text { performed for this point. }\end{array}$ \\
\hline Solimões River after mixing with the Purus River water & $\begin{array}{l}03^{\circ} 37^{\prime} 19.86^{\prime \prime S} ; \\
61^{\circ} 24^{2} 27.23 " \mathrm{~W}\end{array}$ & $4 \mathrm{~S}$ & \begin{tabular}{|l|} 
Depth: $21 \mathrm{~m}$ \\
Sampling depth: $10 \mathrm{~m}$
\end{tabular} & $\begin{array}{l}\text { Sampling data: } 09 / 13 / 2008 \\
\text { Sampling time: } 9: 05 \mathrm{am} \\
\text { Water temperature: } 29.7^{\circ} \mathrm{C} \\
\text { Oxygen: } 4.06 \mathrm{mg} / \mathrm{L} \\
\text { Conductivity: } 63.9 \mu \mathrm{S} / \mathrm{cm} \\
\text { pH: } 6.85 \\
\text { Water transparency: } 55 \mathrm{~cm} \\
\text { Turbidity (NTU): } 0.78 \\
\text { Suspended material }(\mathrm{mg} / \mathrm{L} \text { ): } 71.3\end{array}$ \\
\hline Solimões River & $\begin{array}{l}03^{\circ} 35^{\prime} 43.81^{\prime \prime S} ; \\
6^{\circ} 54^{\prime} 41.68^{\prime \prime} \mathrm{W}\end{array}$ & $3 \mathrm{~S}$ & $\begin{array}{l}\text { Depth: } 20 \mathrm{~m} \\
\text { Sampling depth: } 10 \mathrm{~m}\end{array}$ & $\begin{array}{l}\text { Date of collection: } 09 / 12 / 2008 \\
\text { Sampling time: } 8: 25 \text { am } \\
\text { Water temperature: } 29.8^{\circ} \mathrm{C} \\
\text { Oxygen: } 4.1 \mathrm{mg} / \mathrm{L} \\
\text { Conductivity: } 72.9 \mu \mathrm{S} / \mathrm{cm} \\
\text { pH: } 6.34 \\
\text { Water transparency: } 20 \mathrm{~cm}\end{array}$ \\
\hline Solimões River & $\begin{array}{l}03^{\circ} 17^{\prime} 03.86^{\prime \prime S} ; \\
60^{\circ} 01^{\prime 23.04 " W}\end{array}$ & $1 \mathrm{~S}$ & $\begin{array}{l}\text { Depth: } 21 \mathrm{~m} \\
\text { Sampling depth: } 11 \mathrm{~m}\end{array}$ & $\begin{array}{l}\text { Sampling date: } 09 / 10 / 2008 \\
\text { Sampling time: } 8: 00 \mathrm{am} \\
\text { Water temperature: } 29.7^{\circ} \mathrm{C} \\
\text { Oxygen } 3.76 \mathrm{mg} / \mathrm{L} \\
\text { Conductivity: } 74.4 \mu \mathrm{S} / \mathrm{cm} \\
\text { pH: } 6.59 \\
\text { Water transparency: } 30 \mathrm{~cm} \\
\text { Suspended material }(\mathrm{mg} / \mathrm{L}): 41.33 \\
\text { BOD (mg/L): } 0.55\end{array}$ \\
\hline
\end{tabular}

Genetics and Molecular Research 16 (2): gmr16029567 
The collection, preservation, and analysis of water samples for limnological parameters followed APHA - American Public Health Association and American Water Work Association - AWWA (APHA, 2012). Measurements of in situ parameters (water temperature, $\mathrm{pH}$, turbidity, conductivity, and dissolved oxygen) were carried out in triplicate. The conductivity was measured with a portable conductivimeter YSi model 30. For the measurement of $\mathrm{pH}$, dissolved oxygen and temperature, a portable pHmeter HI8424 and an oximeter model HI 98703 (Hanna Instruments) were used, respectively. Water transparency was measured by Secchi disk. Turbidity was measured using a turbidimeter HI 98703. Suspended material was quantified using gravimetric method D 2540. Dissolved oxygen and the biochemical oxygen demand (BOD) in 5 days at $20^{\circ} \mathrm{C}$ were determined by a modification of the azide method and titration with sodium thiosulfate, by methods $4500 \mathrm{O} \mathrm{C}$ and 5210 B, respectively (APHA, 2012). Sampling procedures in a large river such as the Solimões or access to lakes in that region are quite difficult; due to this a complete metadata acquisition was not possible. An exclusive water column analysis was done because sediments could not be sampled in all sites.

\section{DNA extraction and 16S rRNA gene amplification}

Sterivex filters were filled with extraction buffer ( $40 \mathrm{mM}$ EDTA, $50 \mathrm{mM}$ Tris-HCl, $\mathrm{pH}$ 8.3, and $0.75 \mathrm{M}$ sucrose) and stored at $-20^{\circ} \mathrm{C}$ until DNA extraction. DNA was extracted using the Water Metagenomic DNA Isolation Kit (Epicentre Biotechnologies, Madison, WI, USA). The DNA integrity was confirmed by electrophoresis on a $1 \%$ agarose gel and quantified using the NanoDrop ND-1000 system (Thermo Scientific, Wilmington, DE, USA).

$16 \mathrm{~S}$ rRNA gene sequencing was used to analyze the phylogenetic affiliation of aquatic bacteria and archaea. Gene amplifications were done for bacteria using primers $27 \mathrm{~F}$ and 1492R (Lane, 1991). The PCR was performed using approximately $25 \mathrm{ng}$ metagenomic DNA; $200 \mu \mathrm{M}$ of each dNTP (Promega); 1.25 U Taq DNA polymerase (Fermentas); $1.5 \mathrm{mM}$ $\mathrm{MgCl}_{2}$ (Fermentas); 1X PCR buffer (Fermentas); 10 pmol of each oligonucleotide; and sterile water to achieve a final volume of $25 \mu \mathrm{L}$. The amplification was performed in a PTC-100 thermocycler (MJ Research, Inc.), using the following program: 1 cycle at $94^{\circ} \mathrm{C}$ for $5 \mathrm{~min} ; 35$ cycles at $94^{\circ} \mathrm{C}$ for $1 \mathrm{~min}, 50^{\circ} \mathrm{C}$ for $1 \mathrm{~min}$, and $72^{\circ} \mathrm{C}$ for $2 \mathrm{~min}$; and a final extension at $72^{\circ} \mathrm{C}$ for $20 \mathrm{~min}$.

For archaea, the oligonucleotides used were $21 \mathrm{~F}$ and 958R (DeLong, 1992). The amplification reaction was performed using $25 \mathrm{ng}$ metagenomic DNA; $200 \mu \mathrm{M}$ of each dNTP (Promega); $1 \mathrm{U}$ Taq DNA polymerase (Fermentas); $2.5 \mathrm{mM} \mathrm{MgCl}$ (Fermentas); 1X PCR buffer (Fermentas); $20 \mathrm{pmol}$ of each oligonucleotide; and sterile water to achieve a final volume of $20 \mu \mathrm{L}$. The amplification was performed in a PTC-100 thermocycler (MJ Research, Inc.), using the following program: 1 cycle at $94^{\circ} \mathrm{C}$ for $5 \mathrm{~min} ; 35$ cycles of $94^{\circ} \mathrm{C}$ for $20 \mathrm{~s}, 55^{\circ} \mathrm{C}$ for $30 \mathrm{~s}$, and $72^{\circ} \mathrm{C}$ for $2 \mathrm{~min}$; and a final extension at $72^{\circ} \mathrm{C}$ for $7 \mathrm{~min}$.

The amplification products that were generated for bacteria and archaea were analyzed by electrophoresis on a 1\% agarose gel and visualized under UV light after staining with ethidium bromide. The amplified product bands of the expected size (i.e., $\sim 1500$ and $\sim 900 \mathrm{bp}$ for bacteria and archaea, respectively) were purified from the gel using the Wizard ${ }^{\circledR}$ SV Gel and PCR Clean-Up System kit (Promega, Madison, WI, USA) according to the manufacturer instructions. The products were then visualized on a $1 \%$ agarose gel and quantified using the Nanodrop system.

Genetics and Molecular Research 16 (2): gmr16029567 


\section{Construction of 16S rRNA gene libraries and sequencing}

The purified PCR products were cloned into the pTZ57R/T vector (Fermentas) according to the manufacturer instructions and transformed into competent Escherichia coli DH10B cells (Invitrogen) by electroporation. The cells were cultured on Luria-Bertani (LB) agar (Invitrogen) containing X-gal (USB), IPTG (Invitrogen) and $100 \mu \mathrm{g} / \mathrm{mL}$ ampicillin (Sigma). A total of 13 libraries were constructed for bacterial sequences, including 7 libraries for rivers and 6 libraries for lakes, and 5 libraries were constructed for archaeal sequences, which were all from river samples.

To construct clone libraries, recombinant clones were chosen randomly, subcultured and maintained at $-80^{\circ} \mathrm{C}$ in LB broth containing $10 \%$ glycerol and $100 \mu \mathrm{g} / \mathrm{mL}$ ampicillin. Each clone was cultured in LB broth (Invitrogen) supplemented with $100 \mu \mathrm{g} / \mathrm{mL}$ ampicillin on deep-well microplates, and the cells were harvested by centrifugation and submitted to alkaline lysis plasmid extraction, as described by Vettore et al. (2001).

Clones were sequenced in a MegaBACE 1000 Flexyble system using the DYEnamic ET Dye Terminator Kit for MegaBACE ${ }^{\mathrm{TM}}$ (GE Healthcare). The sequencing primer for bacteria was 338F (Lane, 1991), which extends the V3 hypervariable region of the bacterial 16S rRNA gene, and the M13F primer was used for archaea. Sequences between 400 and 600 bp were used for analyses.

\section{Sequence analysis}

Chromatograms were analyzed using the Sequence Analyzer software program Base Caller Cimarron 3.12, and low-quality sequences (phred $\leq 15$ ) and vectors were removed using the dCas program (Guo et al., 2009). The similarity between sequences containing possible chimeras and diversity indices (i.e., ACE, Shannon, and Simpson) were analyzed using the Mothur software (Schloss et al., 2009).

The obtained sequences were compared to existing rRNA sequences in the EzTaxon database (Chun et al., 2007) and the Mothur (Schloss et al., 2009) software to identify sequences that had an identity percentage greater than $95 \%$ with organisms present in software's databases. Otherwise, only higher taxonomic levels were used. Taxonomic affiliation was obtained by the Mothur analysis (using the Database Project Ribosomal Bank (RDPII) version 10; Cole et al., 2014), complemented with the EzTaxon database (http://eztaxon-e.ezbiocloud.net/) to identify the species (if not identified with Mothur).

\section{Accession Nos.}

Sequence data were deposited in GenBank under the following accession numbers. For bacteria, the sequences and accession Nos. were: 9U (JX670813 - JX671022); 8S (JX671023 - JX671230); 6S (JX671713 - JX671880); 4P (JX672399 - JX672635); 4S (JX672145 - JX672398); 3S (JX672636 - JX672821); 1S (JX673318 - JX673558); 8LP (JX671231 JX671467); 7L (JX671468 - JX671712); 5L (JX671881 - JX672144); 3L (JX672822 JX673063); 2L (JX673064 - JX673317); and 1L (JX673559 - JX673778). For Archaea, the sequences and accession Nos. were: 9U (JX669902 - JX670045); 8S (JX670046 - JX670296); 6S (JX670297 - JX670460); 3S (JX670461 - JX670633); and 1S (JX670634 - JX670812).

Forphylogeny inference, we have used the following sequences as reference: Uncultured

Genetics and Molecular Research 16 (2): gmr16029567 
freshwater LD12 bacterium (Z99997.1); Candidatus Pelagibacter ubique (NR_074224); Candidatus Planktophila limnetica (FJ428831); Polynucleobacter acidiphobus (NR_125545); Polynucleobacter necessarius subsp asymbioticus (NR_074689); Polynucleobacter cosmopolitanus (NR_125487); Polynucleobacter rarus (NR_125547); Ilumatobacter fluminis (NR_041633); Acinetobacter calcoaceticus (NR_117619); Acinetobacter baumannii (CP008706); Acinetobacter junii (NR_117623); Acinetobacter parvus (AB859679).

\section{RESULTS}

Thirteen libraries of the bacterial 16S rRNA gene were built using sequences from 7 locations along the Solimões River, the Urucu River, and the Purus River and 6 lakes adjacent to the Solimões River (details on sampling site in Table 1). The libraries contained 288 sequenced clones for each sample. We used a set of diversity coefficients to determine the microbial diversity in our samples (Table 2).

Table 2. Diversity indices calculated for microbial communities found in lakes and rivers from the Amazon region.

\begin{tabular}{l|c|c|c|c}
\hline Lake group & ACE & Chao & Shannon & Simpson \\
\hline 8LP & 522.329 & 117 & 2.946 & 0.031 \\
\hline 7L & 103.724 & 90.75 & 3.245 & $\mathbf{0 . 0 6 3}$ \\
\hline 5L & $\mathbf{1 4 2 4 . 7 2 7}$ & $\mathbf{3 4 9}$ & $\mathbf{3 . 8 3 7}$ & 0.015 \\
\hline 3L & 179.910 & 116.25 & 3.310 & 0.031 \\
\hline 2L & 133.104 & 173 & 3.606 & 0.012 \\
\hline 1L & 50.192 & 46.25 & 2.897 & 0.025 \\
\hline Average & 402.331 & 148.708 & 3.307 & 0.030 \\
\hline SD & 482.15 & 97.14 & 0.34 & 0.017 \\
\hline River group & & & & 0.033 \\
\hline 9U & 55.210 & 40.5 & 2.762 & 0.094 \\
\hline 8S & 277 & 139.5 & 1.830 & $\mathbf{0 . 2 1 6}$ \\
\hline 6S & 168.192 & 24 & $\mathbf{3 . 6 7 3}$ & 0.012 \\
\hline 4P & 121.099 & 96.8 & 3.072 & 0.046 \\
\hline 3S & $\mathbf{1 5 9 4 . 7 6 6}$ & $\mathbf{3 5 3}$ & 2.362 & 0.140 \\
\hline 1S & 73 & 47.333 & 3.380 & 0.056 \\
\hline Average & 276.063 & 229.25 & 2.794 & 0.085 \\
\hline SD & 366.48 & 132.91 & 0.587 & 0.066 \\
\hline Val & 508.14 & 111.35 & & \\
\hline
\end{tabular}

Values in bold indicate the highest values in each type of environment.

We analyzed the bacterial diversity among samples using these parameters and found no significant differences in the means of the indices tested, using a two-tailed unpaired $t$-test with a 95\% confidence level. However, the Fisher F-test that was performed using the variance, revealed a significant difference $(\mathrm{P}=0.008)$ between the Simpson coefficient values for river and lake samples, indicating a different level of diversity spread in specific types of environment. Samples from the Lake Ananá (5L) and Solimões River (4S) had higher diversity in all analyzed sites, as indicated by at least two indices (ACE and Chao).

We observed a pattern of phyla distribution that correlated with the type of environment (Figures 2, 3, and 4). The Proteobacteria group was the most abundant in all samples with the class Betaproteobacteria being more frequent in nearly all samples (Figures 2 and 3). Members of the phylum Actinobacteria were also observed in all samples from rivers and lakes, accounting for up to $20 \%$ of the total microbial population (Sample 6S, Figure 2). The phyla Bacteroidetes and Verrucomicrobia also represented an important fraction of these freshwater communities (Figures 2 and 3).

Genetics and Molecular Research 16 (2): gmr16029567 


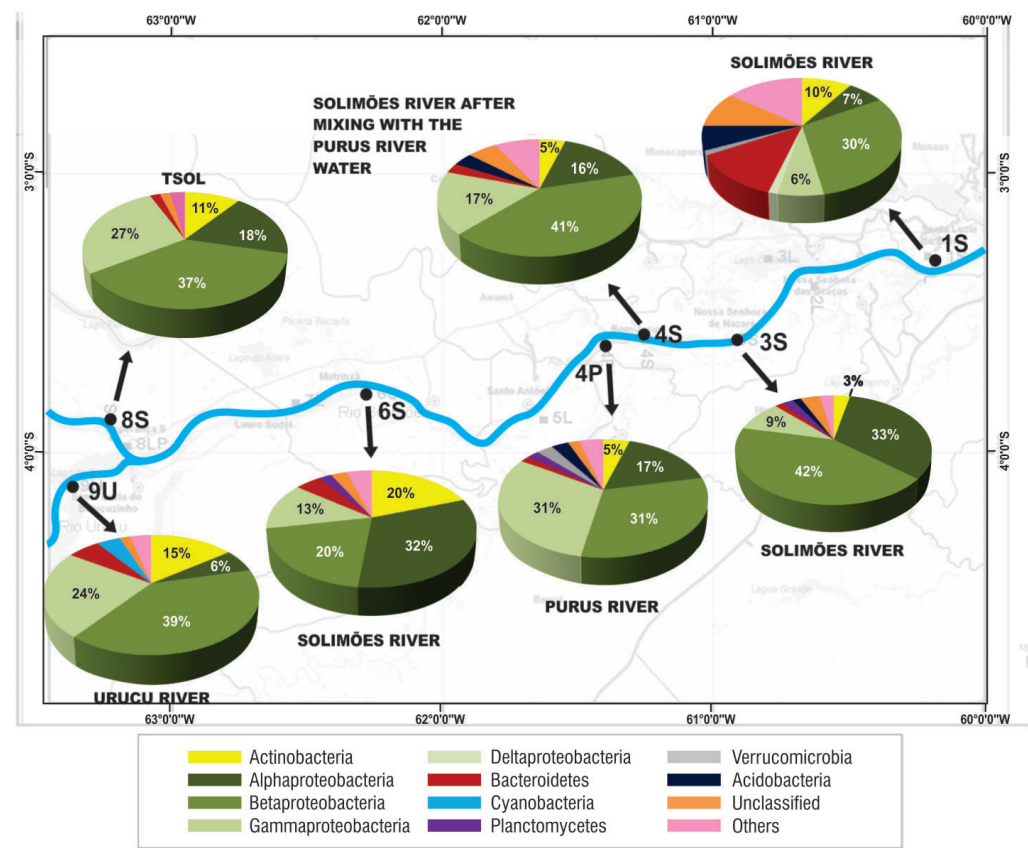

Figure 2. Microbial diversity along the Solimões, Urucu, and Purus Rivers. All samples were normalized by the total number of clones. See Table 1 for further details on the sampling sites.

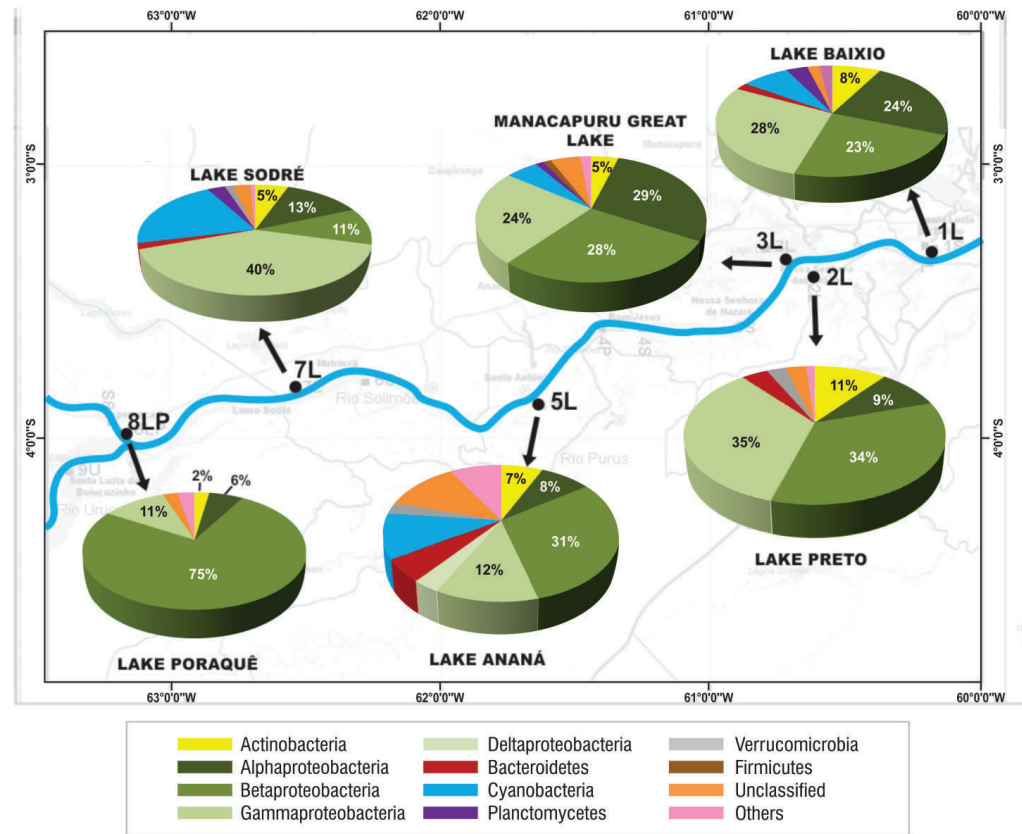

Figure 3. Microbial diversity of the lakes adjacent to the Solimões River. All samples were normalized by the total number of clones. See Table 1 for further details on the sampling sites.

Genetics and Molecular Research 16 (2): gmr16029567 


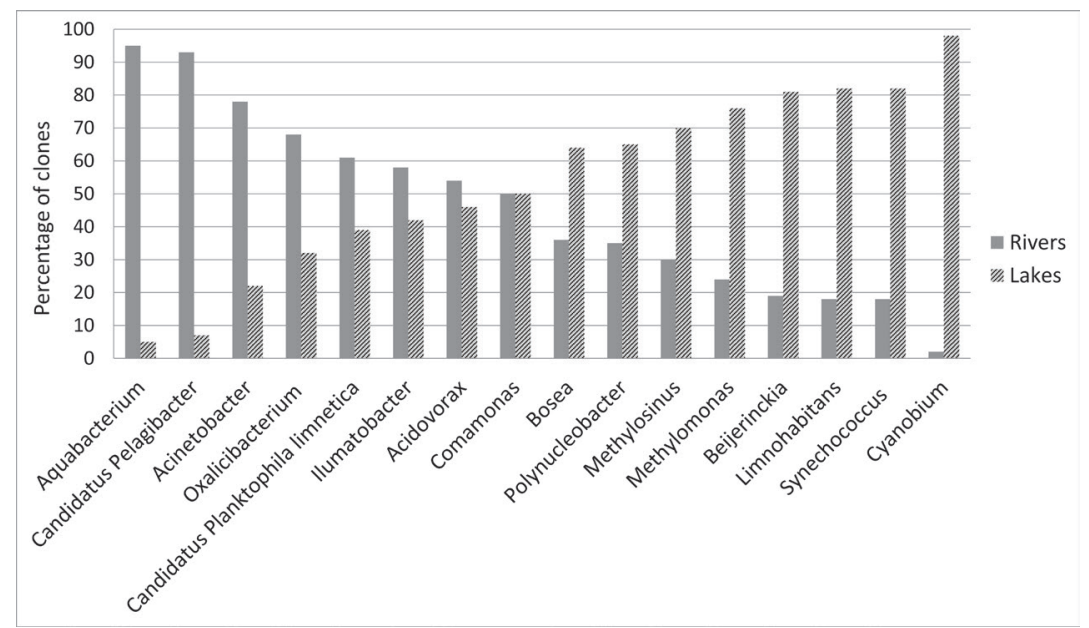

Figure 4. Dominant microorganisms in rivers and lakes. Percentage of clone distribution for each genus among rivers and lakes. The sum of clones for each genus found in lakes and rivers totals $100 \%$.

The genus Polynucleobacter (phylum Proteobacteria, class Betaproteobacteria) (Tables 3 and 4) was present in all samples (rivers and lakes) but was predominant in lake samples (Table 4) and the species Polynucleobater rarus MT-CBb6A5 was identified only in Lake Poraquê (Sample 8LP) using the EzTaxon database.

Table 3. Taxonomic composition of river samples using different approaches.

\begin{tabular}{|c|c|c|c|c|c|c|c|c|c|}
\hline \multirow[t]{2}{*}{ Phylum } & \multirow[t]{2}{*}{ Family } & \multirow[t]{2}{*}{ Genus } & \multicolumn{7}{|c|}{ EzTaxon/Mothur } \\
\hline & & & $9 \mathrm{U}$ & $8 \mathrm{~S}$ & $6 \mathrm{~S}$ & $4 \mathrm{P}$ & $4 \mathrm{~S}$ & $3 \mathrm{~S}$ & $1 \mathrm{~S}$ \\
\hline Actinobacteria & Acidimicrobiaceae & Ilumatobacter & $1 / 8$ & $0 / 4$ & $0 / 5$ & $0 / 5$ & $0 / 1$ & $0 / 3$ & - \\
\hline Proteobacteria & Beijerinckiaceae & Beijerinckia & $1 / 0$ & - & $2 / 2$ & $2 / 3$ & $0 / 1$ & - & $0 / 2$ \\
\hline Proteobacteria & Bradyrhizobiaceae & Bosea & $2 / 0$ & - & - & $4 / 0$ & $2 / 0$ & - & $1 / 0$ \\
\hline Proteobacteria & Burkholderiaceae & Polynucleobacter & $7 / 7$ & $12 / 14$ & $8 / 8$ & $24 / 24$ & $17 / 16$ & $7 / 7$ & $6 / 5$ \\
\hline \multirow{3}{*}{ Proteobacteria } & \multirow{3}{*}{$\underline{\text { Sphaerotilus }}$} & Aquabacterium & $16 / 17$ & $22 / 21$ & - & - & $1 / 0$ & - & - \\
\hline & & Leptothrix & $7 / 0$ & $0 / 1$ & - & $1 / 0$ & $1 / 0$ & - & - \\
\hline & & Methylibium & - & $0 / 4$ & - & - & - & - & - \\
\hline \multirow[t]{4}{*}{ Proteobacteria } & \multirow[t]{4}{*}{ Comamonadaceae } & Acidovorax & $13 / 11$ & $2 / 2$ & $1 / 1$ & $7 / 8$ & $5 / 0$ & $5 / 6$ & $12 / 0$ \\
\hline & & Comamonas & $3 / 0$ & $1 / 0$ & - & $3 / 0$ & $1 / 2$ & $2 / 0$ & $4 / 0$ \\
\hline & & Curvibacter & $1 / 1$ & $1 / 0$ & - & $2 / 3$ & $4 / 4$ & $2 / 1$ & $2 / 0$ \\
\hline & & Hydrogenophaga & $1 / 0$ & - & - & - & $3 / 0$ & - & $0 / 5$ \\
\hline Bacteroidetes & Chitinophagaceae & Sediminibacterium & - & $0 / 1$ & - & - & - & $1 / 1$ & $0 / 4$ \\
\hline Cyanobacteria & Family_II & Gplla & $0 / 9$ & - & - & $0 / 2$ & $0 / 1$ & - & $0 / 2$ \\
\hline \multirow[t]{3}{*}{ Proteobacteria } & \multirow[t]{3}{*}{ Methylococcaceae } & Methylocaldum & - & - & - & $0 / 7$ & - & $0 / 1$ & - \\
\hline & & Methylomonas & - & $0 / 1$ & - & $5 / 5$ & $5 / 5$ & $4 / 6$ & $4 / 4$ \\
\hline & & Methylobacter & - & - & - & $0 / 5$ & - & - & - \\
\hline \multirow[t]{2}{*}{ Proteobacteria } & \multirow[t]{2}{*}{ Methylocystaceae } & Methylocystis & - & - & - & $3 / 4$ & $0 / 3$ & - & $1 / 1$ \\
\hline & & Methylosinus & - & - & - & $3 / 2$ & $3 / 0$ & - & - \\
\hline \multirow[t]{2}{*}{ Proteobacteria } & \multirow[t]{2}{*}{ Methylophilaceae } & Methylotenera & $1 / 0$ & $1 / 0$ & - & - & $4 / 0$ & - & $2 / 0$ \\
\hline & & Methylophilus & $1 / 0$ & $2 / 2$ & $2 / 2$ & $1 / 0$ & $3 / 1$ & - & - \\
\hline Proteobacteria & Moraxellaceae & Acinetobacter & $47 / 47$ & $48 / 52$ & $14 / 15$ & $39 / 41$ & $20 / 20$ & $3 / 3$ & - \\
\hline \multirow{3}{*}{ Proteobacteria } & \multirow{3}{*}{ Oxalobacteraceae } & Herbaspirillum & $0 / 1$ & $1 / 1$ & $0 / 1$ & $1 / 1$ & $3 / 0$ & $0 / 1$ & $1 / 4$ \\
\hline & & Oxalicibacterium & $6 / 0$ & $1 / 0$ & $2 / 1$ & $2 / 0$ & $12 / 0$ & $7 / 0$ & $2 / 0$ \\
\hline & & Undibacterium & - & - & - & $5 / 8$ & $3 / 2$ & - & - \\
\hline Actinobacteria & Planktophila & Candidatus Planktophila limnetica & $2 / 0$ & $2 / 0$ & $7 / 0$ & - & $2 / 0$ & - & $4 / 0$ \\
\hline Cyanobacteria & Prochlorococcaceae & Synechococcus & $6 / 0$ & - & - & - & - & - & $1 / 0$ \\
\hline Proteobacteria & SAR 11 & Pelagibacter & - & $0 / 31$ & $0 / 44$ & $0 / 5$ & - & $0 / 47$ & - \\
\hline Proteobacteria & Sinobacteraceae & Steroidobacter & - & - & $0 / 5$ & - & - & $0 / 1$ & - \\
\hline Proteobacteria & Sphingomonadaceae & Novosphingobium & $1 / 0$ & $4 / 0$ & $1 / 0$ & $0 / 1$ & $1 / 0$ & $2 / 0$ & - \\
\hline
\end{tabular}

Number of clones for each genus present in river samples from the Amazon region was identified by the EzTaxon database and the Mothur software.

Genetics and Molecular Research 16 (2): gmr16029567 
Table 4. Taxonomic composition of lake samples using different approaches.

\begin{tabular}{|c|c|c|c|c|c|c|c|c|}
\hline \multirow[t]{2}{*}{ Phylum } & \multirow[t]{2}{*}{ Family } & \multirow[t]{2}{*}{ Genus } & \multicolumn{6}{|c|}{ EzTaxon / Mothur } \\
\hline & & & $8 \mathrm{LP}$ & $7 \mathrm{~L}$ & $5 \mathrm{~L}$ & $3 \mathrm{~L}$ & $2 \mathrm{~L}$ & $1 \mathrm{~L}$ \\
\hline Actinobacteria & Acidimicrobiaceae & Ilumatobacter & - & $0 / 6$ & $0 / 2$ & $0 / 4$ & $0 / 4$ & $0 / 3$ \\
\hline \multirow[t]{2}{*}{ Proteobacteria } & \multirow[t]{2}{*}{ Beijerinckiaceae } & \multirow{2}{*}{\begin{tabular}{|l|} 
Beijerinckia \\
Methylocella \\
\end{tabular}} & - & $3 / 2$ & - & $8 / 14$ & $2 / 2$ & $9 / 10$ \\
\hline & & & $1 / 0$ & $1 / 0$ & $1 / 0$ & $3 / 2$ & $4 / 0$ & $3 / 1$ \\
\hline Proteobacteria & Bradyrhizobiaceae & Bosea & $2 / 0$ & $4 / 0$ & $2 / 0$ & $3 / 0$ & $2 / 0$ & $3 / 0$ \\
\hline Proteobacteria & Burkholderiaceae & Polynucleobacter & $65 / 67$ & 9/9 & $1 / 0$ & $27 / 26$ & $31 / 31$ & $20 / 24$ \\
\hline \multirow[t]{6}{*}{ Proteobacteria } & \multirow[t]{6}{*}{ Comamonadaceae } & Acidovorax & $11 / 10$ & $3 / 1$ & $12 / 21$ & $6 / 4$ & $4 / 4$ & $3 / 4$ \\
\hline & & Comamonas & $10 / 12$ & - & $2 / 3$ & $0 / 2$ & $1 / 5$ & $1 / 0$ \\
\hline & & Curvibacter & $6 / 0$ & - & $2 / 0$ & $2 / 0$ & $3 / 0$ & - \\
\hline & & Hydrogenophaga & - & - & $1 / 0$ & - & $4 / 0$ & $1 / 0$ \\
\hline & & Limnohabitans & $13 / 0$ & - & $3 / 0$ & - & - & $2 / 0$ \\
\hline & & Pelomonas & - & - & $7 / 7$ & - & - & - \\
\hline Bacteroidetes & Chitinophagaceae & \begin{tabular}{|l|} 
Sediminibacterium \\
\end{tabular} & $1 / 1$ & - & $0 / 1$ & - & $3 / 4$ & $0 / 1$ \\
\hline Cyanobacteria & Family II & Gplla & - & $0 / 50$ & $0 / 28$ & $0 / 10$ & - & $0 / 14$ \\
\hline \multirow[t]{4}{*}{ Proteobacteria } & \multirow[t]{4}{*}{ Methylococcaceae } & Methylocaldum & - & $0 / 5$ & - & - & - & $0 / 10$ \\
\hline & & Methylomonas & - & $2 / 4$ & $6 / 6$ & $5 / 5$ & $36 / 38$ & $8 / 9$ \\
\hline & & Methylosarcina & - & - & - & - & - & $0 / 9$ \\
\hline & & Methylobacter & - & $2 / 23$ & - & - & $1 / 0$ & $0 / 5$ \\
\hline \multirow[t]{2}{*}{ Proteobacteria } & \multirow[t]{2}{*}{ Methylocystaceae } & \begin{tabular}{|l} 
Methylocystis \\
\end{tabular} & - & $0 / 1$ & - & $3 / 11$ & $0 / 1$ & $1 / 3$ \\
\hline & & Methylosinus & - & $2 / 3$ & - & $8 / 0$ & $1 / 0$ & $3 / 1$ \\
\hline Proteobacteria & Methylophilaceae & Methylotenera & $3 / 0$ & - & - & - & $5 / 0$ & - \\
\hline Proteobacteria & Moraxellaceae & Acinetobacter & $14 / 16$ & $26 / 26$ & $8 / 8$ & $1 / 1$ & - & - \\
\hline Verrucomicrobia & Opitutaceae & Opitutus & - & - & $2 / 3$ & - & - & - \\
\hline \multirow[t]{3}{*}{ Proteobacteria } & \multirow[t]{3}{*}{ Oxalobacteraceae } & Duganella & $1 / 2$ & - & $3 / 3$ & - & - & - \\
\hline & & Oxalicibacterium & $1 / 0$ & - & $8 / 0$ & $1 / 0$ & $5 / 0$ & - \\
\hline & & Undibacterium & $1 / 0$ & - & $3 / 7$ & - & - & - \\
\hline Actinobacteria & Planktophila & Candidatus Planktophila limnetica & - & - & - & - & $9 / 0$ & $2 / 0$ \\
\hline \multirow[t]{2}{*}{ Cyanobacteria } & \multirow[t]{2}{*}{ Prochlorococcaceae } & Cyanobium & - & $25 / 0$ & $10 / 0$ & $5 / 0$ & - & $8 / 0$ \\
\hline & & Synechococcus & - & $14 / 0$ & $12 / 0$ & $2 / 0$ & - & $3 / 0$ \\
\hline Proteobacteria & SAR 11 & Pelagibacter & - & $0 / 3$ & $0 / 6$ & - & - & - \\
\hline \multirow[t]{2}{*}{ Proteobacteria } & \multirow[t]{2}{*}{ Sphingomonadaceae } & Novosphingobium & $2 / 2$ & - & $6 / 6$ & $2 / 1$ & - & - \\
\hline & & Sphingomonas & - & - & $3 / 3$ & - & - & - \\
\hline
\end{tabular}

The number of clones for each genus present in lake samples from the Amazon region was identified by the EzTaxon database and the Mothur software.

In the phylum Actinobacteria, our analyses revealed the presence of candidate species Candidatus Planktophila limnetica in the Amazon rivers and lake samples (Tables 3 and 4).

Methanotrophic bacteria were also observed in the Amazon samples (Tables 3 and 4), as well as the typically marine genus Ilumatobacter (Figure 4), Candidatus Pelagibacter spp that were abundant in river samples (Figure 4), and some cyanobacterium clones, mostly represented by Cyanobium and Synechococcus, which were present in nearly all lake samples (Figures 3 and 4).

The distribution of the different genera in river and lake samples is shown in Figure 4. The genera Aquabacterium (95\%) and Acinetobacter (78\%) were more abundant in river samples, while the cyanobacteria from genera Synechococcus (82\%) and Cyanobium (98\%) were more abundant in the lake samples.

The data presented in Figure 5 reveal the relationship of the representative clones from the 16S rRNA libraries from Amazon rivers and lakes with the species Candidatus Pelagibacter ubique, putative LD12 sequence and Ilumatobacter fluminis.

We also found members of archaea in the Solimões River (i.e., sample points 1S, 3S, 6S, and 8S) and the Urucu River (i.e., sample point 9U), with nearly 200 sequenced clones from each sample. As a whole, our samples from the Amazon exhibited a remarkable predominance of Thaumarchaeota phylum in all compiled libraries. Few sequences related to the phyla Crenarchaeota and Euryarchaeota were found (Figure 6). 


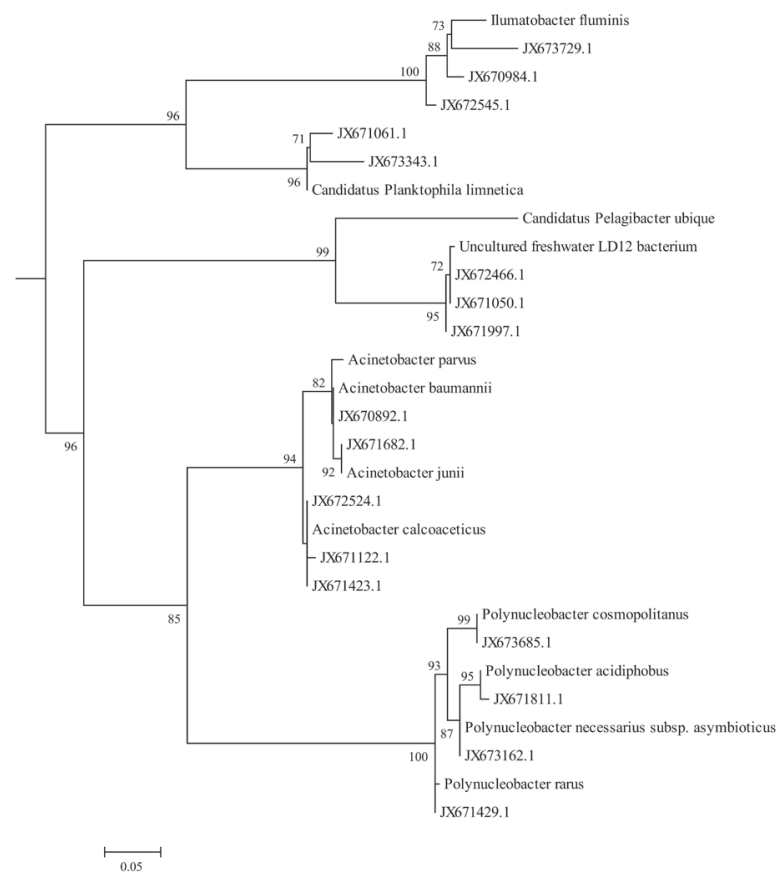

Figure 5. Phylogenetic relationships between the main clones. A phylogenetic analysis of representative clones from the 16S rRNA libraries of samples from rivers and lakes in the Amazon region was performed using the MEGA 6.03 program. The analysis used the ML algorithm and the Kimura-2-parameter model and gamma distribution with 5 parameters, assuming non-invariable sites, and bootstrapping with 1000 iterations. Node support above the $70 \%$ confidence level is shown.

\section{Archaea}

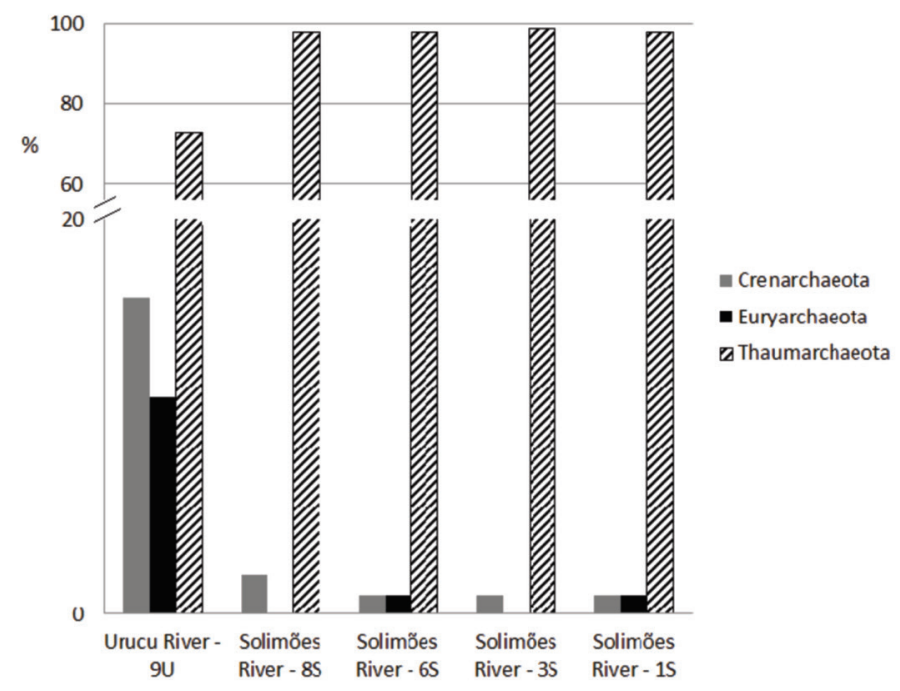

Figure 6. Archaea taxa distribution. Percentage of archaeal phyla in five river samples.

Genetics and Molecular Research 16 (2): gmr16029567 


\section{DISCUSSION}

A $1.3 \%$ or greater sequence difference in the $16 \mathrm{~S}$ rRNA gene (based on the fulllength sequence) is often used to define different species (Stackebrandt and Ebers, 2006). In this sense, species abundance models can be used regardless of coverage, which is useful in bacterial diversity analysis and can address the distribution in an entire sample (Hill et al., 2003). Thus, this approach facilitates comparison by revealing overall trends and even specific changes in the abundance of particular classes (Hill et al., 2003).

In our 16S rRNA gene clone libraries, we found a clear pattern in the frequency of phylogenetic groups retrieved from each environment (river or lake), which could be related to environmental conditions observed in the different sampling sites (Figure 4). Despite the apparent separation, lakes and rivers are connected geographically, and the biodiversity revealed by qualitative parameters showed that all points represent a dynamic, complex and unique system. No clustering patterns could be observed within any analysis adopting genetic proximity, metadata (from available sites) or microbial data (data not shown).

The most diverse samples were located in the middle portion of the river (i.e., Solimões), particularly in samples derived from the $4 \mathrm{~S}$ and $5 \mathrm{~L}$ sampling sites. The Solimões River sampling site 4S was located downstream the confluence with Purus River (Figure 2), which might have exerted an additive effect on the main river microbial community. The Purus is a large tributary and might have enriched the main river with new taxa, nutrients and also additional carbon sources. The river stretches located downstream to the confluence zones are known to be hotspots for bacterial metabolism (Farjalla, 2014). Our results indicate that such synergetic effects might also occur in bacterial community structure, with higher diversity after the confluence of a tributary. Whether this increase in diversity is just a circumstantial observation or endures downstream with the active growth of some of the taxa deserves to be further explored in future studies.

Lake Ananá (5L) site is a lentic environment with relatively high levels of dissolved oxygen $(4.14 \mathrm{mg} / \mathrm{L})$, which might be indicative of the presence of a high phytoplankton biomass. Phytoplankton-derived organic carbon is a labile carbon source for bacteria, especially in tropical regions where high temperature and light conditions enhance algal extracellular release of organic compounds (Morana et al., 2014) that probably support the establishment of complex microbial communities with diverse ecological roles.

The main taxa contributions to diversity were reinforced by recent studies which showed, through next-generation sequencing, that Proteobacteria group and Actinobacteria are the most abundant taxa in rivers (Santos-Júnior et al., 2017) and lakes (Toyama et al., 2016). However, differences in proportions were observed due to the more sensitive methodology used in those studies.

The genus Polynucleobacter (Tables 3 and 4) also was abundant in the lower Amazon River, as previously observed by Satinsky et al. (2015). This is a widely distributed taxon in both lentic and lotic habitats worldwide (Hahn, 2003; Jezberová et al., 2010). Several cultivation-independent studies that were performed in freshwater, marine and terrestrial habitats reported that the genus Polynucleobacter has a widespread distribution in freshwater environments (Zwart et al., 2002; Jezberová et al., 2010). Like Watanabe et al. (2009), Jezberová et al. (2010) suggested that the cluster Polynucleobacter prefers environments with a high concentration of dissolved organic matter and that these bacteria can use substrates produced by the photodegradation of humic substances. The low conductivity of Lake Poraquê

Genetics and Molecular Research 16 (2): gmr16029567 
(8LP) (Table 1) and its classification as black water, which is rich in humic compounds, can justify the higher abundance of the genus Polynucleobacter at this site in comparison to all of the other sampling locations (Tables 3 and 4). Polynucleobater rarus is considered rare due to its preference for acidic environments (Hahn et al., 2011), which is consistent with our observations. Lake Poraque has a $\mathrm{pH}$ value of 5 , while the $\mathrm{pH}$ values of the other samples are close to neutral (Table 1).

The phylum Actinobacteria composes a large fraction of the bacterioplankton in freshwater environments (Jezbera et al., 2009). This group of freshwater Actinobacteria includes organisms called the "acl" lineage. These organisms often represent one of the most abundant lineages (Zwart et al., 2002; Newton et al., 2007) and are widely distributed along the water column of freshwater habitats (Lindström et al., 2005; Newton et al., 2007) in several continents and climatic zones but are not observed in terrestrial and marine (i.e., open sea) environments (Jezbera et al., 2009). Jezbera et al. (2009) proposed the candidate species Candidatus Planktophila limnetica as a representative of the "acl" lineage. Newton et al. (2007) reported that the members of the acI clade AII, such as Candidatus Planktophila limnetica, exhibit a preference for alkaline lakes (i.e., $\mathrm{pH} 8.6$ to 8.9), which can explain the low representation of this species in our sampling sites, where the $\mathrm{pH}$ ranged from 5 to 7 .

The genus Acinetobacter of the class Gammaproteobacteria was also well represented in our samples (Tables 3 and 4). Acinetobacter is metabolically versatile, and the ability of the members of this genus to degrade aliphatic hydrocarbons (e.g., crude petroleum and fuels, as well as aromatic hydrocarbons) has great potential for bioremediation studies (Jung et al., 2010). Jurelevicius et al. (2013) showed that crude oil- and heptadecane-enriched operational taxonomic units in freshwater microcosms were represented mainly by the genus Acinetobacter. Furthermore, the hydrocarbon composition might affect the presence of Acinetobacter species. This preference for a certain compound may be used for biomonitoring and bioremediation studies.

Although these bacteria have the ability to degrade hydrocarbons, no major petroleum spills have been reported in our sampled regions. In fact, there are boats traveling up and down Amazonian rivers that might enhance the presence of petroleum hydrocarbons in the water and/or in the sediment. This might also contribute to support known degrading oil bacterial genera. Furthermore, the Urucu oil and gas production province is situated about $280 \mathrm{~km}$ west of sample $8 \mathrm{~S}$. Such an oil and gas prone region may be extended up to the vicinities of Coari, which includes samples $9 \mathrm{U}$ and 8S (upstream of Coari terminal in the Solimões River), where Acinetobacter occur in large quantities, compared with the rest of the studied area. An interesting hypothesis to be tested in future research is if the large presence of these organisms, particularly in samples $9 \mathrm{U}$ and $8 \mathrm{~S}$, might serve as an indicator of natural petroleum seepage for further oil and gas exploration and may be used for bioremediation and biomonitoring studies.

Methanotrophic bacteria, for example, the genus Methylomonas, were frequently found, particularly in Lake Preto (2L). These bacteria are significant in global methane consumption and play an important role in the carbon cycle, in both aquatic and terrestrial environments (Auman et al., 2000). Freshwater sediments are believed to contribute 40 to $50 \%$ of the annual flow of methane in the atmosphere (Auman et al., 2000).

In a recent study in the lower Amazon River, it has also been reported the presence of the genus Ilumatobacter (Satinsky et al., 2015). This genus belongs to the phylum Actinobacteria, and species of Ilumatobacter were found inhabiting marine environments such as sediment of the estuaries, seashores and marine sponges. Thus, marine water or artificial marine water 
was believed to be required for the development of this species (Matsumoto et al., 2009). The genus was dominant in the brackish water Lake Sayram (China), and it was suggested that this genus might play an important role in the metabolism of the lake (Fang et al., 2015). Actually, besides reports of its presence in some environments, there are no comprehensive studies available on the ecology of Ilumatobacter.

Candidatus Pelagibacter spp were one of the most abundant organisms in our clone libraries (i.e., $21 \%$ of the total sequences). The SAR11 clade, to which Candidatus Pelagibacter spp belongs, is frequently observed in marine environments and was previously considered to be rare or absent in freshwater environments, as it is adapted to oligotrophic conditions (Salcher et al., 2011). However, a sister group from freshwater environments (i.e., LD12) may perform similar functions in those habitats (Zwart et al., 2002). This result corroborates with a previous study (Ghai et al., 2011) in the Solimões River (sample point 8S) where sequences associated with Candidatus Pelagibacter ubique accounted for 15\%. In Figure 5, we can observe this relationship, our clones with the species Candidatus Pelagibacter ubique and putative LD12 sequence.

Filamentous or coccoid cyanobacteria larger than $5 \mu \mathrm{m}$ were not the focus of this study, and most of them were probably removed by the filtration procedure (prefiltration through a 5-mm membrane filter) during sample collection. Still, we retrieved some cyanobacteria represented by Cyanobium and Synechococcus. The genus Synechococcus is the dominant picocyanobacteria in freshwater habitats and its abundance is high in tropical lakes (Sarmento et al., 2008). This genus contributes significantly to global primary production in all climatic zones and can also be observed in extreme habitats, including hot springs and hypersaline lagoons. In our analyses, sequences associated with the freshwater species Cyanobium gracile PCC 6370 were also observed. This species has been isolated from temperate lake zones in Europe, America, and Japan (Ernst et al., 2003). It reinforces the ubiquitous presence of these taxa since Cyanobium and Synechococcus are widespread in freshwater.

Archaea are prokaryotes that were previously considered to be extremophiles but are now characterized as inhabitants of a diverse array of habitats (Chaban et al., 2006). Borneman and Triplett (1997) were the first to report on the microbial diversity in soils of Amazon region using cultivation-independent molecular methods. Nearly $2 \%$ of the clones identified by those authors were classified as archaea. Our study also demonstrated the presence of archaea in Amazon aquatic environments (Figure 6). The phylum Thaumarchaeota was initially classified as mesophilic Crenarchaeota and is considered the most abundant phylum of the Archaea domain. This phylum is largely distributed in terrestrial and aquatic environments with moderate temperatures. The organisms of this phylum oxidize ammonia, contributing to the global nitrogen and carbon cycles, and are critical to the environment (Pester et al., 2011).

\section{CONCLUSION}

In summary, this study reveals the existence of an extensive microbial diversity in both rivers and lakes of the Amazon region. Samples from the Lake Ananá (5L) and Solimões River (4S) after the confluence with Purus River had the highest diversity, measured as alpha diversity indexes. The most widely distributed taxon (i.e., Polynucleobacter) was found in all sampling sites. Although genus Polynucleobacter is widespread, sequences related to rare species inside it, such as Polynucleobacter rarus, were retrieved only from Lake Poraquê (8LP). Previously reported Actinobacteria species and archaea related to the freshwater environment

Genetics and Molecular Research 16 (2): gmr16029567 
were also identified in the upper Solimões River region, showing its ecological balance and pristine profile. Although these environments did not show many differences about the species found, they were different concerning the proportion of these species. Environmental features like $\mathrm{pH}$, conductivity, type of water (black or white), and the difference between systems (lotic and lentic) showed to influence the bacterium abundance. For instance, cyanobacteria in lentic sampled sites $(7 \mathrm{~L}, 5 \mathrm{~L}$, and $1 \mathrm{~L})$.

\section{Conflicts of interest}

J.W. Garcia is employed by Noosfera Projetos Especiais Ltda. in São Paulo, Brazil. F.P. Miranda is employed by Petróleo Brasileiro S.A. - Petrobras in Brazil, in Rio de Janeiro, Brazil.

\section{ACKNOWLEDGMENTS}

Research supported by Petróleo Brasileiro S.A. (Petrobras) as part of a research agreement (\#0050.0081178.13.9) with the Federal University of São Carlos, SP, Brazil, within the context of the Geochemistry Thematic Network. F. Henrique-Silva is the recipient of a Research Productivity Scholarship from Conselho Nacional de Desenvolvimento Científico e Tecnológico (CNPq \#311745/2013-0). D. Toyama was the recipient of a master scholarship from Coordenação de Aperfeiçoamento de Pessoal de Nível Superior (CAPES). H. Sarmento was supported by CNPq (Process \#303341/2013-0) and FAPESP (Process \#2014/14139-3). We thank Marcelo Paustein Moreira, Fundação Vitória Amazônica (FVA), Diego Peruchi Trevisan (UFSCar), and Dr. Luiz Eduardo Moschini (UFSCar) for helping us with the map presented in Figure 1. We also thank Dr. Adriana Ururahy Soriano (PETROBRAS, CENPES) for critically reading the manuscript and providing helpful suggestions.

\section{REFERENCES}

APHA - American Public Health Association American Water Work Association - AWWA (2012). Standard methods of the experimentation of water and wastewater. Water Pollution Control Federation - WPCF, New York.

Auman AJ, Stolyar S, Costello AM and Lidstrom ME (2000). Molecular characterization of methanotrophic isolates from freshwater lake sediment. Appl. Environ. Microbiol. 66: 5259-5266. http://dx.doi.org/10.1128/AEM.66.12.5259$\underline{5266.2000}$

Borneman J and Triplett EW (1997). Molecular microbial diversity in soils from eastern Amazonia: evidence for unusual microorganisms and microbial population shifts associated with deforestation. Appl. Environ. Microbiol. 63: 26472653.

Chaban B, Ng SY and Jarrell KF (2006). Archaeal habitats--from the extreme to the ordinary. Can. J. Microbiol. 52: 73116. http://dx.doi.org/10.1139/w05-147

Chun J, Lee JH, Jung Y, Kim M, et al. (2007). EzTaxon: a web-based tool for the identification of prokaryotes based on 16S ribosomal RNA gene sequences. Int. J. Syst. Evol. Microbiol. 57: 2259-2261 http://dx.doi.org/10.1099/ijs.0.64915-0.

Cole JR, Wang Q, Fish JA, Chai B, et al. (2014). Ribosomal Database Project: data and tools for high throughput rRNA analysis. Nucleic Acids Res. 42: D633-D642 http://dx.doi.org/10.1093/nar/gkt1244.

DeLong EF (1992). Archaea in coastal marine environments. Proc. Natl. Acad. Sci. USA 89: 5685-5689. http://dx.doi. org/10.1073/pnas.89.12.5685

Ernst A, Becker S, Wollenzien UIA and Postius C (2003). Ecosystem-dependent adaptive radiations of picocyanobacteria inferred from 16S rRNA and ITS-1 sequence analysis. Microbiology 149: 217-228 http://dx.doi.org/10.1099/ mic. $0.25475-0$.

Fang L, Chen L, Liu Y, Tao W, et al. (2015). Planktonic and sedimentary bacterial diversity of Lake Sayram in summer. MicrobiologyOpen 4: 814-825 http://dx.doi.org/10.1002/mbo3.281.

Genetics and Molecular Research 16 (2): gmr16029567 
Farjalla VF (2014). Are the mixing zones between aquatic ecosystems hot spots of bacterial production in the Amazon River system? Hydrobiologia 728: 153-165 http://dx.doi.org/10.1007/s10750-014-1814-8.

Ghai R, Rodriguez-Valera F, McMahon KD, Toyama D, et al. (2011). Metagenomics of the water column in the pristine upper course of the Amazon river. PLoS One 6: e23785 http://dx.doi.org/10.1371/journal.pone.0023785.

Glöckner FO, Fuchs BM and Amann R (1999). Bacterioplankton compositions of lakes and oceans: a first comparison based on fluorescence in situ hybridization. Appl. Environ. Microbiol. 65: 3721-3726.

Guo Y, Ribeiro JM, Anderson JM and Bour S (2009). dCAS: a desktop application for cDNA sequence annotation. Bioinformatics 25: 1195-1196 http://dx.doi.org/10.1093/bioinformatics/btp129.

Hahn MW (2003). Isolation of strains belonging to the cosmopolitan Polynucleobacter necessarius cluster from freshwater habitats located in three climatic zones. Appl. Environ. Microbiol. 69: 5248-5254 http://dx.doi.org/10.1128/ AEM.69.9.5248-5254.2003.

Hahn MW, Lang E, Tarao M and Brandt U (2011). Polynucleobacter rarus sp. nov., a free-living planktonic bacterium isolated from an acidic lake. Int. J. Syst. Evol. Microbiol. 61: 781-787 http://dx.doi.org/10.1099/ijs.0.017350-0.

Hill TC, Walsh KA, Harris JA and Moffett BF (2003). Using ecological diversity measures with bacterial communities. FEMS Microbiol. Ecol. 43: 1-11 http://dx.doi.org/10.1111/j.1574-6941.2003.tb01040.x.

Jezbera J, Sharma AK, Brandt U, Doolittle WF, et al. (2009). 'Candidatus Planktophila limnetica', an actinobacterium representing one of the most numerically important taxa in freshwater bacterioplankton. Int. J. Syst. Evol. Microbiol. 59: 2864-2869 http://dx.doi.org/10.1099/ijs.0.010199-0.

Jezberová J, Jezbera J, Brandt U, Lindström ES, et al. (2010). Ubiquity of Polynucleobacter necessarius ssp. asymbioticus in lentic freshwater habitats of a heterogeneous $2000 \mathrm{~km}$ area. Environ. Microbiol. 12: 658-669 http://dx.doi. org/10.1111/j.1462-2920.2009.02106.x.

Jung J, Baek JH and Park W (2010). Complete genome sequence of the diesel-degrading Acinetobacter sp. strain DR1. J. Bacteriol. 192: 4794-4795 http://dx.doi.org/10.1128/JB.00722-10.

Jurelevicius D, Alvarez VM, Marques JM, de Sousa Lima LRF, et al. (2013). Bacterial community response to petroleum hydrocarbon amendments in freshwater, marine, and hypersaline water-containing microcosms. Appl. Environ. Microbiol. 79: 5927-5935 http://dx.doi.org/10.1128/AEM.02251-13.

Lane DJ (1991). 16S/23S rRNA sequencing. In Stackebrandt, E., and Goodfellow, M. (eds.), Nucleic acid techniques in bacterial systematics. John Wiley \& Sons, New York, 115-175.

Lemke MJ, Lienau EK, Rothe J, Pagioro TA, et al. (2009). Description of freshwater bacterial assemblages from the upper paraná river floodpulse system, Brazil. Microb. Ecol. 57: 94-103 http://dx.doi.org/10.1007/s00248-008-9398-3.

Lindström ES, Kamst-Van Agterveld MP and Zwart G (2005). Distribution of typical freshwater bacterial groups is associated with pH, temperature, and lake water retention time. Appl. Environ. Microbiol. 71: 8201-8206 http:// dx.doi.org/10.1128/AEM.71.12.8201-8206.2005.

Matsumoto A, Kasai H, Matsuo Y, Omura S, et al. (2009). Ilumatobacter fluminis gen. nov., sp. nov., a novel actinobacterium isolated from the sediment of an estuary. J. Gen. Appl. Microbiol. 55: 201-205 http://dx.doi.org/10.2323/jgam.55.201.

Mayorga E, Aufdenkampe AK, Masiello CA, Krusche AV, et al. (2005). Young organic matter as a source of carbon dioxide outgassing from Amazonian rivers. Nature 436: 538-541. $\underline{\text { http://dx.doi.org/10.1038/nature03880 }}$

Mertes LAK, Dunne T and Martinelli LA (1996). Channel-floodplain geomorphology along the Solimões-Amazon River, Brazil. GSA Bull 108: 1089-1107. http://dx.doi.org/10.1130/0016-7606(1996)108<1089:CFGATS >2.3.CO;2

Morana C, Sarmento H, Descy J-P, Gasol JM, et al. (2014). Production of dissolved organic matter by phytoplankton and its uptake by heterotrophic prokaryotes in large tropical lakes. Limnol. Oceanogr. 59: 1364-1375 http://dx.doi. org/10.4319/lo.2014.59.4.1364.

Newton RJ, Jones SE, Helmus MR and McMahon KD (2007). Phylogenetic ecology of the freshwater Actinobacteria acI lineage. Appl. Environ. Microbiol. 73: 7169-7176 http://dx.doi.org/10.1128/AEM.00794-07.

Nishimura Y and Nagata T (2007). Alphaproteobacterial dominance in a large mesotrophic lake (Lake Biwa, Japan). Aquat. Microb. Ecol. 48: 231-240 http://dx.doi.org/10.3354/ame048231.

Oltman RE (1968). Reconnaissance investigations of the discharge and water quality of the Amazon River. United States Geological Survey, Washington, D.C. pp.16.

Pester M, Schleper C and Wagner M (2011). The Thaumarchaeota: an emerging view of their phylogeny and ecophysiology. Curr. Opin. Microbiol. 14: 300-306 http://dx.doi.org/10.1016/j.mib.2011.04.007.

Read DS, Gweon HS, Bowes MJ, Newbold LK, et al. (2015). Catchment-scale biogeography of riverine bacterioplankton. ISME J. 9: 516-526 http://dx.doi.org/10.1038/ismej.2014.166.

Salcher MM, Pernthaler J and Posch T (2011). Seasonal bloom dynamics and ecophysiology of the freshwater sister clade of SAR11 bacteria 'that rule the waves' (LD12). ISME J. 5: 1242-1252 http://dx.doi.org/10.1038/ismej.2011.8.

Santos-Júnior CD, Kishi LT, Toyama D, Soares-Costa A, et al. (2017). Metagenome sequencing of prokaryotic microbiota

Genetics and Molecular Research 16 (2): gmr16029567 
collected from rivers in the Upper Amazon Basin. Genome Announc. 5: e01450-e16 http://dx.doi.org/10.1128/ genomeA.01450-16.

Sarmento H, Unrein F, Isumbisho M, Stenuite S, et al. (2008). Abundance and distribution of picoplankton in tropical, oligotrophic Lake Kivu, eastern Africa. Freshw. Biol. 53: 756-771 http://dx.doi.org/10.1111/j.13652427.2007.01939.x.

Satinsky BM, Fortunato CS, Doherty M, Smith CB, et al. (2015). Metagenomic and metatranscriptomic inventories of the lower Amazon River, May 2011. Microbiome 3: 39 http://dx.doi.org/10.1186/s40168-015-0099-0.

Schloss PD, Westcott SL, Ryabin T, Hall JR, et al. (2009). Introducing mothur: open-source, platform-independent, community-supported software for describing and comparing microbial communities. Appl. Environ. Microbiol. 75: 7537-7541 http://dx.doi.org/10.1128/AEM.01541-09.

Stackebrandt E and Ebers J (2006). Taxonomic parameters revisited: tarnished gold standards. Microbiol. Today 33: 152-155.

Toyama D, Kishi LT, Santos-Júnior CD, Soares-Costa A, et al. (2016). Metagenomics Analysis of Microorganisms in Freshwater Lakes of the Amazon Basin. Genome Announc. 4: e01440-e16 http://dx.doi.org/10.1128/ genomeA.01440-16.

Vettore AL, Da Silva FR, Kemper EL and Arruda P (2001). The libraries that made SUCEST. Genet. Mol. Biol. 24: 1-7. http://dx.doi.org/10.1590/S1415-47572001000100002

Watanabe K, Komatsu N, Ishii Y and Negishi M (2009). Effective isolation of bacterioplankton genus Polynucleobacter from freshwater environments grown on photochemically degraded dissolved organic matter. FEMS Microbiol. Ecol. 67: 57-68 http://dx.doi.org/10.1111/j.1574-6941.2008.00606.x.

Zwart G, Crump BC, Kamst-Van Agterveld MP, Hagen F, et al. (2002). Typical freshwater bacteria: an analysis of available 16S rRNA gene sequences from plankton of lakes and rivers. Aquat. Microb. Ecol. 28: 141-155 http:// dx.doi.org/10.3354/ame028141.

Genetics and Molecular Research 16 (2): gmr16029567 